\title{
EFEITO DA ESTOCAGEM E DAS CONDIÇÕES DE COLHEITA SOBRE ALGUMAS PROPRIEDADES FÍSICAS, QUIMICAS E NUTRICIONAIS DE TRÊS CULTIVARES DE FEIJÃO (Phaseolus vulgaris, L.) ${ }^{1}$
}

\author{
Alessandro de Oliveira RIOS ${ }^{2, *}$, Celeste Maria Patto de ABREU ${ }^{3}$, Angelita Duarte CORREA ${ }^{4}$
}

\section{RESUMO}

O feijão é um dos alimentos encontrados em maior quantidade em todo o território nacional. Por proporcionar nutrientes essenciais é utilizado como alternativa em substituição a carnes ou outros produtos protéicos pela população de baixa renda. A baixa digestibilidade das proteínas do feijão, quando comparada às proteinas animais, é um de seus problemas nutricionais, fator este que pode ser reduzido dependendo das condições de armazenamento. O objetivo deste trabalho foi avaliar o efeito da estocagem e das condições de colheita sobre algumas propriedades físicas, químicas e nutricionais de três cultivares de feijão. Os resultados demostraram que os teores médios de umidade foram mais elevados antes do armazenamento e após o armazenamento os grãos atingiram um equilíbrio higroscópico com o ambiente nos três cultivares. Os cultivares colhidos antecipadamente apresentaram-se com maior capacidade de absorção de água e esta reduziu ao longo do periodo de armazenamento nas duas épocas de colheita. O teor de compostos fenólicos apresentou-se mais elevado nas amostras colhidas antecipadamente, o que nos leva a concluir que estes compostos não estariam afetando a capacidade de hidratação dos grãos. As cultivares colhidas antecipadamente apresentaram valores mais elevados de proteina. Após o período de armazenamento, os feijões apresentaram um conteúdo de proteína ligeiramente mais alto. A digestibilidade tende a diminuir com os meses de armazenamento. Reação entre proteínas e fenóis durante o processamento de feijão pode estar relacionada à menor digestibilidade devido à correlação negativa entre digestibilidade in vitro e o teor de taninos presentes no produto.

Palavras-chave: armazenamento; colheita; digestibilidade; proteína, feijão.

\section{SUMMARY}

EFFECT OF STORAGE AND HARVEST CONDITIONS ON SOME PHYSICAL, CHEMICAL AND NUTRITIOUS PROPERTIES OF THREE BEAN CULTIVARS (Phaseolus vulgaris, L.). In Brazil, bean stands out as one of the most important food and it is found nationwide. Providing essential nutrients, it is utilized an as alternative, in substituting of meats or other proteic products, but it presents some problems like low digestibility if compared to animal proteins, which can be reduced under special storage conditions. This research aimed to evaluate the effect of storage and harvest conditions on some nutritious, physical and chemical properties of three bean cultivars. The results show that the average moisture contents were higher before storage and, after storage, the grains came into hygroscopic equilibrium with the environment in the studied cultivars. Early harvested cultivars presented higher water-absorbing capacity, which reduced during the storage period at the harvested samples. The level of phenolic compounds was higher in early harvested samples, which makes us conclude that these compounds would not be affecting the grain hydration capacity. The early harvested samples presented higher values of protein. After storage period, beans presented protein content slightly higher. The digestibility reduced during the months of storage. Reaction between proteins and phenols in processing may be associated to the low digestibility due to the negative correlation between the in vitro digestibility and tannin content present in the product. Keywords: storage; harvest; digestibility; protein; bean.

\section{1- INTRODUÇÃO}

O feijão é um produto tradicional na alimentação da população brasileira, principalmente das classes de menor renda. Em função de suas condições climáticas, o Brasil produz feijão praticamente o ano todo. Os feijões consumidos no Brasil pertencem à classe Dicotiledoneae, família Fabaceae (Leguminosae), gênero Phaseolus e espécie Phaseolus vulgaris L.

Sob o ponto de vista nutricional o feijão apresenta componentes e características que tornam seu consumo vantajoso. Entre eles, pode-se citar o conteúdo protéico relativamente alto, o teor elevado de lisina, que exerce efeito complementar às proteinas dos cereais, a fibra alimentar com seus reconhecidos efeitos

${ }_{1}^{1}$ Recebido para publicação em 07/08/2001. Aceito para publicação em 20/08/2003 (000705).

${ }^{2}$ DCA, Universidade Federal de Lavras (UFLA), CP: 37, CEP: 37200-000, Lauras-MG.E-mail:aorios@uol.com.br.

${ }^{3}$ DQI, Universidade Federal de Lauras (UFLA), CP: 37, CEP: 37200-000, Lauras-MG. E-mail: celeste@ufla.br.

${ }^{4}$ DQI, Universidade Federal de Lauras (UFLA), CP: 37, CEP: 37200-000, Lavras-MG.E-mail: angelita@ufla.br.

* A quem a correspondencia deve ser enviada. hipocolesterolêmico e hipoglicêmico, o alto conteúdo de carboidratos complexos e a presença de vitaminas do complexo B. Por outro lado, alguns problemas nutricionais como a baixa digestibilidade protéica, o conteúdo reduzido em aminoácidos sulfurados, a presença de fatores antinutricionais e a baixa disponibilidade de minerais são assuntos que têm merecido a atenção especial de vários grupos de pesquisas [13].

Por proporcionar nutrientes essenciais é utilizado como alternativa em substituição a carnes ou outros produtos protéicos. O feijão pode contribuir com até $28 \%$ de proteinas e $12 \%$ de calorias ingeridas. Portanto, como alimento básico e sob o ponto de vista quantitativo, o feijão é considerado um alimento protéico, embora seu conteúdo calórico, mineral e vitamínico não possa ser desprezado.

A qualidade culinária do feijão é consideravelmente afetada à medida que se aumentam os meses de armazenamento, preferindo o consumidor produto de colheita mais recente. A perda de qualidade manifesta-se pelo aumento no grau de dureza do feijão, com conseqüentes acréscimos no tempo necessário para cozimento, além de mudanças no sabor e escurecimento do tegumento 
em alguns cultivares [18]. Alguns produtores sob a alegação de que feijões colhidos antecipadamente tendem a apresentar menor escurecimento do tegumento antecipam a colheita dos mesmos e evitam estocar o produto por períodos prolongados.

SGARBIERI [19] relata que o feijão sofre perdas de sua qualidade durante o armazenamento, sendo alguma delas: desenvolvimento de casca dura (hardshell), que impede a reidratação dos grãos, fenômeno favorecido por uma baixa umidade relativa na atmosfera de armazenagem e um alto conteúdo de umidade nas sementes; e endurecimento ou perda das propriedades de cocção dos cotilédones (hard-to-cook), fenômeno reversivel e com velocidade dependente principalmente da temperatura ambiental e da umidade relativa da atmosfera de armazenamento.

A baixa digestibilidade das proteinas do feijão, quando comparada à proteínas animais, é um de seus problemas nutricionais, fator este que pode ser reduzido dependendo das condições de armazenamento [15].

Não adianta obter produtos de alta qualidade se os mesmos não forem conservados adequadamente. A conservação inadequada ocasiona deterioração do produto, o que leva a sua depreciação pelo consumidor.

A fim de preservar a qualidade pós-colheita, originando menores perdas, com conseqüente aumento de ganhos, no presente trabalho, objetivou-se determinar o teor de umidade, capacidade de absorção de água, compostos fenólicos, digestibilidade in vitro e fração protéica em três cultivares de feijão comum, após uma colheita antecipada, após colheita em tempo normal e nos períodos de armazenamento de 2, 4, 6 e 8 meses.

\section{2 - MATERIAL E MÉTODOS}

O material utilizado no presente estudo foi fornecido pelo Departamento de Biologia, Setor de Genética e Melhoramento de Plantas da Universidade Federal de Lavras (UFLA)/Lavras/MG. Utilizaram-se feijões dos cultivares ESAL 550, CI 128 e Carioca. Destes materiais estudados, os dois primeiros foram cultivados no Campus da UFLA e o cultivar Carioca em propriedade rural, localizada no municipio de Lavras, durante os meses de janeiro a abril de 1998 (época da seca), e colhidos no mês de maio de 1998 .

O cultivar ESAL 550 apresenta grão amarelo; hábito de crescimento indeterminado - III; ciclo normal (120 dias). O cultivar CI 128 apresenta grão tipo grande, bege com estrias marrons; hábito de crescimento indeterminado - II; porte ereto com guias curtas; ciclo normal. O cultivar Carioca apresenta grão tipo carioca, bege com estrias marrons; hábito de crescimento indeterminado - III; ciclo normal.

A colheita dos cultivares foi realizada em duas datas, uma colheita antecipada (cerca de 15 dias antes da colheita normal) e a colheita normal (120 dias), quando $90 \%$ das vagens estavam secas. Após a colheita, os feijões, ainda com a palha, foram submetidos a uma se- cagem natural no Departamento de Biologia da UFLA. O produto permaneceu em terreiro cimentado para secagem por 3 dias. Após a secagem, as amostras foram acondicionadas em sacos de papel e devidamente identificadas e armazenadas.

No início do armazenamento, para as duas épocas de colheita, o teor de umidade dos cultivares foram de 15,10\%, 14,19\% e 13,12\% para o feijão Carioca, CI 128 e ESAL 550, respectivamente.

As amostras de feijão foram moídas e submetidas as análises de fração protéica e digestibilidade in vitro logo após a secagem natural do feijão e nos períodos de armazenamento de 2, 4, 6 e 8 meses. O armazenamento foi realizado no Laboratório de Bioquímica da UFLA, sob condições ambientais, sendo que a temperatura média registrada neste período foi de $20^{\circ} \mathrm{C}$ e a umidade relativa média de $71,9 \%$ (média dos meses de maio de 1998 a janeiro de 1999).

O teor de umidade foi determinado por secagem em estufa a $105^{\circ} \mathrm{C}$ até a obtenção de peso constante, segundo procedimento da AOAC [3].

As amostras de feijão foram submetidas ao teste de absorção de água, durante o periodo de 14 horas, e a cada intervalo de uma hora, as amostras foram pesadas. A relação água destilada e peso de amostra foi de (4/1), ou seja $80 \mathrm{~g}$ de água destilada para cada $20 \mathrm{~g}$ da amostra de feijão. Inicialmente colocou-se em cada becker de $100 \mathrm{~mL}$, uma cesta de plástico de mesma forma e tamanho; logo em seguida, adicionaram-se 80g de água destilada. Feito isso, foi retirada a cesta de cada becker e quantificou-se o peso (cesta + água destilada) após um período de 2 minutos de descanso, correspondendo a um fator de correção. Logo após, $20 \mathrm{~g}$ de amostra foram pesadas e adicionadas em cada becker contendo água destilada e cesta. Assim, iniciou-se a contagem do tempo de absorção de água. Após cada intervalo de uma hora, retirou-se a cesta, deixando descansar durante um periodo de 2 minutos e, em seguida, as amostras foram pesadas (cesta + água destilada + amostra). Após o intervalo de 14 horas, foi calculada a quantidade de água absorvida pelas amostras. A capacidade de absorção máxima é aparente, pois a quantidade de água foi calculada na base de ganho de peso [9].

Os compostos fenólicos foram extraídos pelo método de SWAIN \& HILLIS [21] utilizando metanol (80\%) como extrator, e quantificados de acordo com o método de Folin - Denis, descrito pela AOAC [3].

A digestibilidade in vitro foi determinada de acordo com a técnica descrita por AKESSON \& STAHMANN [1]. Uma amostra equivalente a $8 \mathrm{mg}$ de nitrogênio foi pesada e utilizada para a determinação da digestibilidade. Utilizou-se a caseína como padrão de comparação.

A determinação da fração protéica foi realizada pelo método Kjeldahl (semi-micro), conforme procedimento da AOAC [3]. Os resultados foram expressos em gramas de proteina por 100 gramas de amostra in natura ou seca, empregando-se 6,25 como fator de conversão de nitrogênio. 
As comparações múltiplas entre as médias dos parâmetros estudados foram realizadas utilizando-se o teste de Tukey ao nivel de 5\% de probabilidade. Os modelos de regressão polinomiais foram selecionados com base na significância do teste de $\mathrm{F}$ de cada modelo testado e, também pelo coeficiente de determinação, segundo GOMES [11].

\section{3 - RESULTADOS E DISCUSSÃO}

\section{1 - Teor de umidade}

As curvas de umidade dos três feijões estão representadas nas Figuras 1 e 2, nas quais observa-se que estas apresentaram a mesma tendência nos dois tipos de colheita.

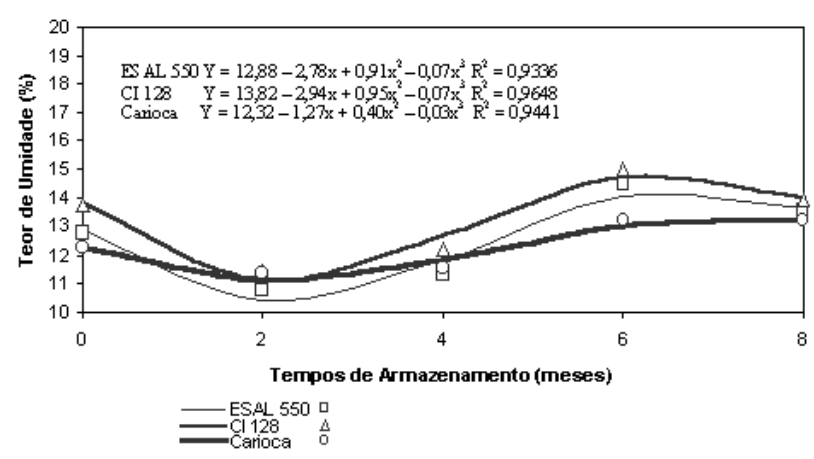

FIGURA 1. Curvas e equações representativas dos valores de umidade de três cultivares de feijão colhidos antecipadamente e armazenados durante 8 meses

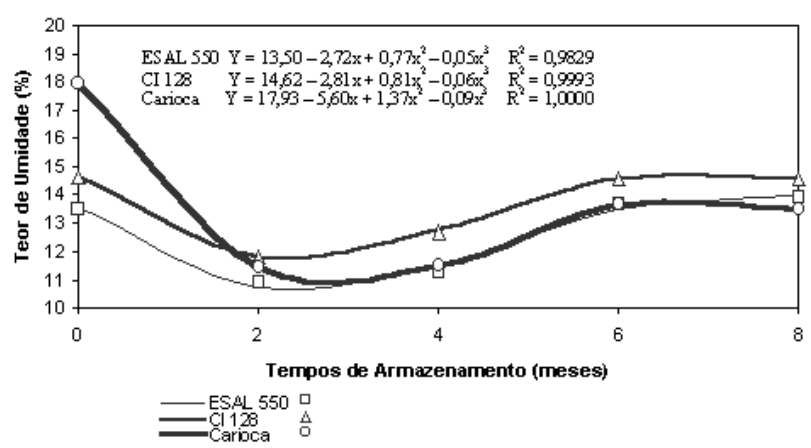

FIGURA 2. Curvas e equações representativas dos valores de umidade de três cultivares de feijão colhidos em época normal e armazenados durante 8 meses.

O teores médios de umidade dos cultivares CI 128 , ESAL 550 e Carioca foram de 13,26\%; 12,57\% e 12,32\%, respectivamente para a colheita antecipada e de 13,64\%; $12,57 \%$ e $13,59 \%$ para a colheita normal.

Os resultados mostram que durante o periodo de armazenamento o teor de umidade decresceu. No início do armazenamento, para as duas épocas de colheita, o teor de umidade dos cultivares eram estatisticamente diferentes, sendo que o cultivar Carioca era o que se apresentava, em termos médios, com valor mais elevado (15,10\%), seguido dos cultivares CI 128 (14,19\%) e ESAL 550 (13,12\%). Durante os períodos de armazena- mento, os teores de umidade mostraram a mesma tendência nos três cultivares.

O teor de umidade para a colheita normal, no início do armazenamento, era de $15,33 \%$, e para colheita antecipada, de $12,94 \%$, valores que diferem estatisticamente entre si. Porém, nos demais períodos de armazenamento e também ao final deste, quando se comparam épocas de colheita, os teores de umidade não foram estatisticamente diferentes entre si.

Em termos médios, o cultivar CI 128 foi o que apresentou maior teor de umidade $(13,45 \%)$ e o cultivar ESAL 550, o menor $(12,61 \%)$. A colheita normal apresentou o maior teor de umidade $(13,29 \%)$ em relação à colheita antecipada $(12,71 \%)$. Ambos os valores estão dentro do padrão ideal citado por BRAGANTINI [4].

Durante o segundo mês de armazenamento, tanto para colheita normal quanto para a colheita antecipada, ocorreu uma queda brusca no teor de umidade dos três cultivares. Este fato pode ser explicado devido aos grãos apresentarem, no início do armazenamento, um teor de umidade mais elevado e também devido ao fato da umidade relativa neste período ser mais baixa, em termos médios de $66,5 \%$. Após o segundo mês de armazenamento, a umidade relativa do ambiente tendeu a elevar-se, e no final de 8 meses, esta umidade encontrava-se em termos médios de $76 \%$.

A umidade e temperatura do local de armazenamento podem afetar características dos grãos armazenados. Os cultivares foram estocados em um ambiente com temperatura média de $20^{\circ} \mathrm{C}$ e umidade relativa média de $71,9 \%$, valores que, segundo vários autores, contribuem para a manutenção da qualidade dos grãos.

BUNCH [8] destaca em seu trabalho, que para feijão a umidade é um importante fator na manutenção da qualidade do produto, tanto para aquele que será destinado ao consumo como para aquele feijão que será utilizado posteriormente como semente.

\section{2 - Capacidade de absorção de água}

A colheita antecipada das amostras e o armazenamento por um periodo de 8 meses afetou de forma significativa a capacidade de hidratação.

O cultivar CI 128 foi o que apresentou a maior capacidade de absorção de água, em relação aos outros dois cultivares, para as duas épocas de colheita, tendo um valor médio de $129,06 \%$ de água absorvida em relação ao seu peso inicial. A amostra de CI 128 colhida antecipadamente absorveu maior quantidade de água (130,68\% em média, em relação ao peso inicial) que a amostra do mesmo cultivar colhida em época normal $(127,84 \%$ em média, em relação ao peso inicial). Nas Figuras 3 e 4 estão representadas as capacidades de absorção de água dos cultivares CI 128 e ESAL 550 durante o período de armazenamento. O armazenamento reduz a capacidade de absorção dos grãos, pois para a colheita antecipada, o cultivar CI 128 absorveu 132,83\% de água em relação ao seu peso inicial no início do armazenamento, e ao final dos 8 meses a amostra absorveu 
125,70\%. O mesmo ocorre para o mesmo cultivar colhido em época normal, na qual a capacidade de absorção reduz de $131,34 \%$ para $126,35 \%$ durante todo armazenamento.

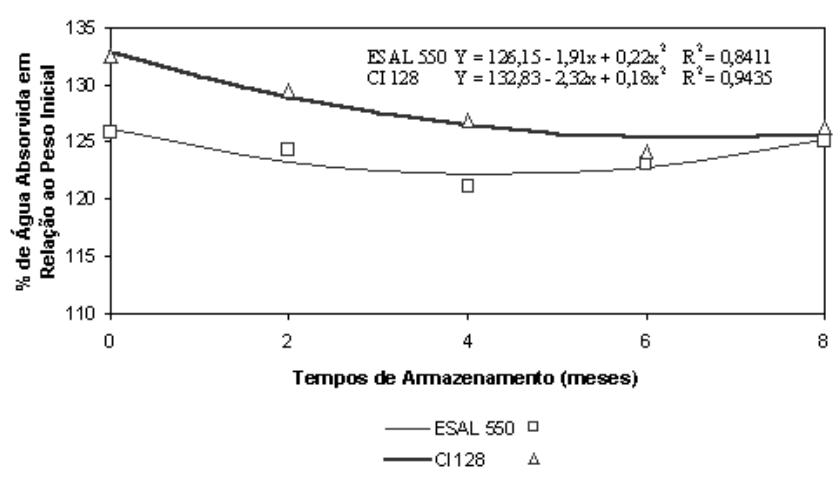

FIGURA 3. Curvas e equações representativas dos valores de capacidade de absorção de água de dois cultivares de feijão colhidos antecipadamente e armazenados durante 8 meses.

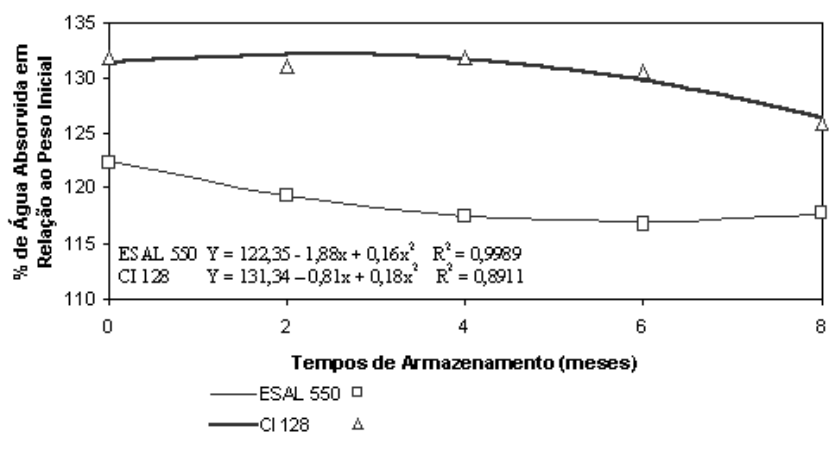

FIGURA 4. Curvas e equações representativas dos valores de capacidade de absorção de água de dois cultivares de feijão colhidos em época normal e armazenados durante 8 meses.

O cultivar ESAL 550 foi o cultivar intermediário, apresentando, em média, capacidade de absorção de 121,27\% em relação ao seu peso inicial. Da mesma forma que o cultivar CI 128, a amostra que apresentou maior capacidade de absorção foi aquela colhida antecipadamente $(123,84$ \% comparados com $118,69 \%$ em relação ao peso inicial). Durante o armazenamento, a capacidade de absorção para este cultivar reduz de $126,15 \%$ para $125,11 \%$ na colheita antecipada e de $122,35 \%$ para $117,61 \%$ na colheita normal.

Para o cultivar Carioca houve significância para regressão até 3 o grau nas duas épocas de colheita estudadas $(121,71 \%$ na colheita antecipada e $114,42 \%$ na colheita normal), porém não foi possivel ajustar a equação.

O cultivar Carioca possui menor capacidade de absorção de água, em média de 118,06\%. Na amostra colhida antecipadamente, encontraram-se valores médios de $121,71 \%$ de água absorvida em relação ao seu peso inicial e a amostra colhida em época normal 114,42\%. Em ambas as épocas de colheita, a capacidade de absorção reduz com o tempo de armazenamento. A colhei- ta antecipada apresentou melhor absorção de água em relação à colheita normal.

No processamento industrial do feijão, é muito importante a sua preparação para o cozimento. O feijão é comumente embebido em água, à temperatura ambiente, por um periodo de aproximadamente 12 a 14 horas. Isto faz com que se reduza o tempo de cozimento. Vários pesquisadores mostraram que este tempo de embebição é suficiente para hidratar feijões secos que serão enlatados, embora a taxa de embebição é influenciada pelo tipo de feijão, nivel de umidade, idade, etc. [14].

GARRUTI [10] comenta em seu estudo que a embebição de até 12 horas não provoca qualquer alteração na composição centesimal e no valor nutritivo do feijão. Segundo a pesquisadora o amolecimento dos grãos é devido à desnaturação protéica e à hidrólise de carboidratos.

O tempo de cozimento prolongado é conseqüência do endurecimento do grão, que ocorre durante o armazenamento. Este aumento no tempo de cozimento está também relacionado com a capacidade de absorção de água, segundo GUEVARA [12].

A oxidação de taninos no tegumento da semente pode restringir a mobilidade de água e então contribuir para a condição de hardshell durante o armazenamento [20].

\section{3 - Compostos fenólicos}

O cultivar ESAL 550 foi o que apresentou o maior teor de fenólicos totais entre os cultivares estudados, tendo um teor médio de $829,93 \mathrm{mg}$ de equivalentes de ácido tânico/100g de tecido b. s. Como mostram as Figuras 5 e 6, o maior teor de fenólicos ocorreu para este cultivar tanto na colheita antecipada quanto na colheita normal, sendo este valor mais elevado na colheita antecipada (850, 88mg de equivalentes de ácido tânico/ $100 \mathrm{~g}$ de tecido b.s na colheita antecipada e $808,98 \mathrm{mg}$ de equivalentes de ácido tânico/100g de tecido b.s na colheita normal).

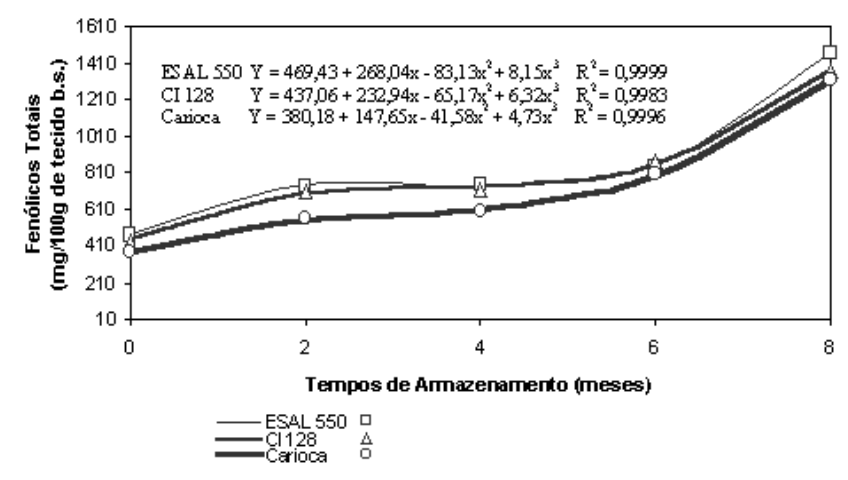

FIGURA 5. Curvas e equações representativas dos valores de fenólicos totais de três cultivares de feijão colhidos antecipadamente e armazenados durante 8 meses.

No cultivar CI 128, o teor médio de fenólicos foi de $786,79 \mathrm{mg}$ de equivalentes de ácido tânico/100g de tecido b. s. Da mesma forma que o cultivar ESAL 550 o teor 
de fenólicos é superior na amostra colhida antecipadamente $(815,81 \mathrm{mg}$ de equivalentes de ácido tânico/ 100 $\mathrm{g}$ de tecido b.s comparados com $757,76 \mathrm{mg}$ de equivalentes de ácido tânico/100g da colheita normal).

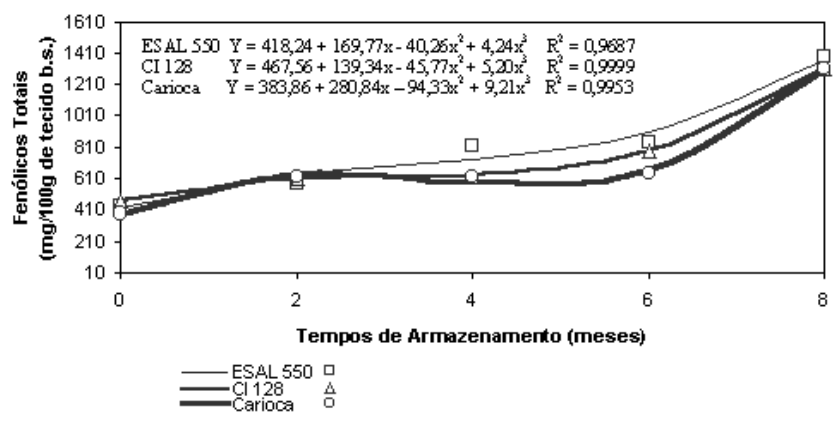

FIGURA 6. Curvas e equações representativas dos valores de fenólicos totais de três cultivares de feijão colhidos em época normal e armazenados durante 8 meses.

O cultivar Carioca foi o que apresentou menor nivel de fenólicos totais $(722,76 \mathrm{mg}$ de equivalentes de ácido tânico/100g de tecido b.s) e como os demais cultivares a amostra colhida antecipadamente apresentou um teor mais elevado $(729,30$ e $716,22 \mathrm{mg}$ de equivalentes de ácido tânico/100g de tecido b.s).

Para todos os cultivares analisados, o maior teor de fenólicos totais ocorreu ao final do período de 8 meses de armazenamento, tanto na colheita antecipada como na normal.

Nas duas épocas de colheita estudadas, o teor de fenólicos aumentou durante o periodo de armazenamento para todos os cultivares. Contudo, nas amostras colhidas antecipadamente esse aumento foi maior que na colheita normal.

Após o sexto mês de armazenamento, notou-se um escurecimento do tegumento dos feijões. Resultados emelhantes foram encontrados por IADEROZA et al. [13], que trabalhando com armazenamento de feijão por 6 meses em temperatura de $25^{\circ} \mathrm{C}$ encontrou um aumento no teor de taninos para os cultivares Carioca 80 e Aroana.

O teor de polifenóis parece não estar influenciando a capacidade de hidratação dos grãos, pois para os três cultivares colhidos antecipadamente, as amostras apresentaram maior capacidade de absorção de água e também maior teor de compostos fenólicos. Da mesma forma, o cultivar Carioca foi o que apresentou menor capacidade de hidratação e menor teor de compostos fenólicos ao final do período de armazenamento. A não lignificação do tegumento pode estar influenciando este fenômeno.

O cultivar ESAL 550 foi o que apresentou maior escurecimento do tegumento durante o armazenamento, fato que está de acordo com os resultados encontrados por MOURA [17], que avaliando compostos fenólicos nos cultivares Carioca MG, Carioca e linhagem $\mathrm{H} 4$, encontrou, no cultivar Carioca MG, após o armazenamento, maior teor destes compostos e observou também um maior escurecimento do tegumento em relação aos demais. O mesmo autor também encontrou um menor nivel de compostos fenólicos totais para a linhagem H4 $(291,55 \mathrm{mg}$ de equivalentes de ácido tânico/100g de tecido b. s), que é o que apresenta tegumento branco.

TIBÚRCIO [22] constatou que o teor de polifenóis em feijão, independente das condições de estocagem e época de plantio, é cerca de 7 a 11 vezes maior na casca que no resto do grão.

BRESSANI, HERNANDEZ \& BRAHAM [7] demonstraram em seu trabalho que existe estreita relação entre a intensidade de coloração da casca e do conteúdo de polifenóis. Segundo os autores, pode-se supor que quanto mais pigmentada a casca, maior a concentração destes compostos no grão.

\section{4 - Fração protéica}

Como mostra a Tabela 1, o cultivar Carioca é o único que difere estatisticamente dentro do fator época de colheita. Quando este cultivar foi colhido antecipadamente, apresentou um valor alto de proteina bruta $(30,41 \%)$, e quando a colheita foi normal, ele mostrou ser o cultivar com menor valor protéico $(24,11 \%)$.

TABELA 1. Teores médios de proteína bruta (\%) dos três cultivares de feijōes.

\begin{tabular}{ccc}
\hline & \multicolumn{2}{c}{ Colheita } \\
\cline { 2 - 3 } Cultivar & Antecipada & Normal \\
\hline Carioca & 30,41 a A & 24,11 b C \\
CI 128 & 28,16 a B & 28,26 a A \\
ESAL 550 & 26,22 a C & 25,56 a B
\end{tabular}

* Médias seguidas de mesmas letras minúsculas nas linhas e maiúsculas nas colunas não diferem entre si pelo teste de Tukey ao nivel de $5 \%$ de probabilidade.

Os cultivares CI 128 e ESAL 550 não apresentaram diferença estatística para o fator época de colheita.

Quando compara-se cultivares, todos os três estudados apresentaram diferença entre si no valor de proteína bruta tanto na colheita antecipada como na colheita normal. O cultivar Carioca colhido antecipadamente apresentou um valor alto de proteina bruta e o cultivar CI 128 um valor intermediário e o cultivar ESAL 550 um valor baixo. Porém o perfil se altera na colheita normal.

MARTIN-CABREJAS et al. [16] trabalhando com cinco variedades de feijão, demostraram que o conteúdo de proteina em feijões crus alterou de $18,2 \%$ a $23,3 \%$. Segundo os autores, de um modo geral feijões armazenados têm um conteúdo de proteína ligeiramente mais alto, dados que estão de acordo com os encontrados neste trabalho.

\section{5 - Digestibilidade in vitro}

Em termos médios, o cultivar Carioca foi o que apresentou melhor digestibilidade $(52,81 \%)$ quando compa- 
rado com os cultivares ESAL 550 (52,70\%) e CI 128 $(48,83 \%)$, porém não se detectou diferença significativa entre os cultivares Carioca e ESAL 550. Para os feijões estudados, somente houve diferença significativa para o fator época de colheita no cultivar ESAL 550, o qual apresentou-se com melhor digestibilidade para a amostra colhida antecipadamente $(55,24 \%)$, comparados à colheita normal $(50,18 \%)$.

Apesar da colheita antecipada apresentar maior teor de proteína, a digestibilidade não mostrou diferença significativa entre as épocas de colheita para os demais cultivares.

De um modo geral, a digestibilidade tende a diminuir com os meses de armazenamento, conforme observado nas Figuras 7 e 8.

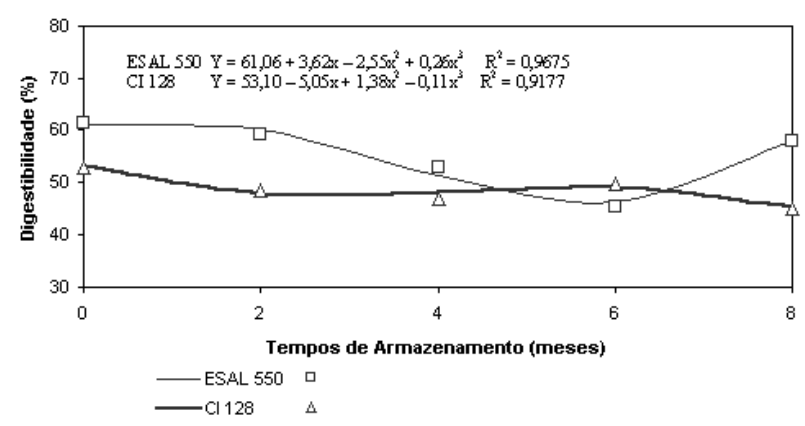

FIGURA 7. Curvas e equações representativas dos valores de digestibilidade de dois cultivares de feijão colhidos antecipadamente e armazenados durante 8 meses.

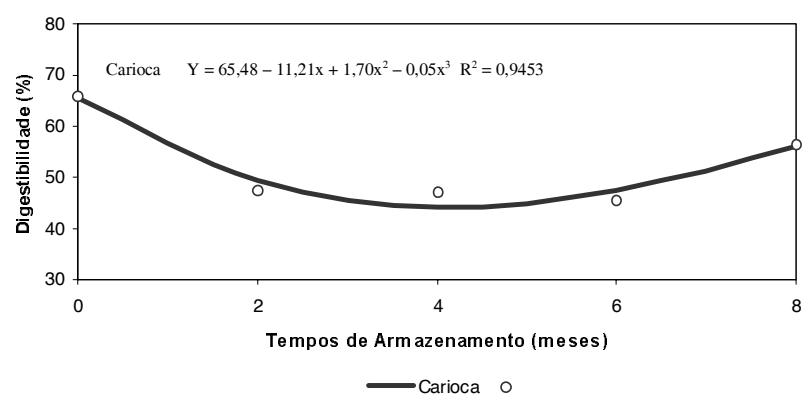

FIGURA 8. Curva e equação representativa dos valores de digestibilidade do cultivar Carioca colhido em época normal e armazenado durante 8 meses.

A digestibilidade do cultivar Carioca da colheita antecipada foi significativo na curva de regressão com um valor médio de 53,09\%, porém não foi possivel ajustar a equação. O mesmo fato foi verificado para os cultivares ESAL 550 e CI 128 na colheita normal com valores médios de $50,18 \%$ e 49,08\% respectivamente, onde houve significância para regressão até $3^{\circ}$ grau, porém não foi possivel ajustar a equação.

Ao final do período de 8 meses de armazenamento nas amostras que foram colhidas antecipadamente, 0 cultivar CI 128 (45,23\%) foi o que apresentou menor digestibilidade, e nas amostras colhidas em época normal, a menor digestibilidade foi para o cultivar ESAL 550. O cultivar Carioca apresentou um ligeiro aumento na digestibilidade provavelmente devido a uma menor interação entre os compostos fenólicos e proteínas.

BRESSANI [5] aponta a reduzida digestibilidade das proteínas do feijão (e de outras leguminosas) como sendo multicausal, sugerindo a ação de fatores ligados à casca (taninos), aos cotilédones (inibidores de natureza protéica, taninos, fitatos, inibidores de proteases) e ao processamento e armazenamento.

BRESSANI, HERNADEZ \& BRAHAM [7] sugerem dois mecanismos que poderiam explicar o efeito de polifenóis na redução da digestibilidade protéica: reação entre proteínas e fenóis durante o processamento de feijão e, ou, entre fenóis e enzimas do trato digestivo. Ainda demostraram que a influência da concentração de taninos na digestibilidade da proteína e qualidade do feijão se expressa pela correlação negativa entre a digestibilidade in vitro e teor de taninos presentes no produto.

Estes dados de digestibilidade encontrados estão de acordo com SGARBIERI et al. [19], que avaliando a digestibilidade tanto in vitro como em animais, verificou que esta situa-se entre 40 e 70\%. BRESSANI [6] avaliando a digestibilidade em humanos, também encontrou valores baixos, cerca de $55 \%$.

ANTUNES \& SGARBIERI [2] verificaram a influência do armazenamento por 6 meses de feijão da variedade Rosinha G2 sob três diferentes condições de temperatura e umidade: condição $\mathrm{A}-12^{\circ} \mathrm{C}$ a $52 \%$ UR, condição B $25^{\circ} \mathrm{C}$ a $65-70 \%$ UR e condição $\mathrm{C}-37^{\circ} \mathrm{C}$ a $76 \%$ UR. A digestibilidade de proteína mudou de $62,4 \%$ para $58,9 \%, 57,1 \%$ e 54,4\% para as condições A, B e C, respectivamente.

\section{4 - CONCLUSÕES}

A época de colheita influenciou todos os parâmetros estudados com exceção da digestibilidade. Na colheita antecipada os cultivares apresentaram maiores valores de capacidade de absorção de água, fenólicos totais e proteina bruta. Porém, os resultados sugerem que esta colheita não trouxe vantagem em relação à colheita normal, pois para digestibilidade não houve diferença significativa.

O armazenamento ocasiona prejuizos na capacidade de absorção de água e digestibilidade dos cultivares.

O cultivar ESAL 550 é o mais afetado em suas propriedades físico-químicas. Dentro de todo período de armazenamento, o cultivar Carioca foi o que apresentou melhores características.

\section{5 - REFERÊNCIAS BIBLIOGRÁFICAS}

[1] Akesison, W. R.; StAhMAnn, M. A. A pepsin pancreatin digest index of protein quality evoluation. Journal of Nutrition, Buthesda, v. 83, p. 257-261, 1964.

[2] ANTUNES, P. L.; SGARBIERI, V. C. Influence of time and conditions of storage on technological and nutritional properties of a dry bean. (Phaseolus vulgaris L.) variety Rosinha G2. Journal of Food Science, Chicago, v. 44, n.6, p. 1703-1706, 1979. 
[3] A.O.A.C. - ASSOCIATION OF OFFICIAL ANALYTICAL CHEMISTS. Official methods of analysis. 15 ed., Washington, 1990.

[4] BRAGANTINI, C. Produção de sementes. In: ARAUJO, R. S.; AGUSTÍN RAVA, C.; STONE, L. F.; ZIMMERMANN, M. J. de O. (coords.). Cultura do feijoeiro comum no Brasil. Piracicaba: Potafos, Sç. 4, p. 639-667, 1996.

[5] BRESSANI, R. Grain quality of common beans. Food Reviews International, New York, v.9, p. 237-97, 1993.

[6] BRESSANI, R. Research needs to up-grade the nutritional quality of common beans (Phaseolus vulgaris). Qualitas Plantarum Plant Foods for Human Nutrition, Netherlands, v. 32, p. 101-10, 1983.

[7] BRESSANI, R.; HERNANDEZ, E.; BRAHAM, E. Relationship between content and intake of bean polphenolics and protein digestibility in humans. Plant Foods for Human. Nutrition, Dordrecht, v.38, p. 5-21, 1988.

[8] BUNCH, H. D. Temperature, relative humidities factores in maintaining store seed viability. Seedsmen's Digest. Oct, 1959.

[9] DOVLO, F. E. Criteria for cooking quality and acceptability of cowpeas. In: HULSE, J.; RACHIE, D. O.; BILLINGSLEY, L. W. Nutritional standards and methods of evaluation for food legume breeders. Ottawa: IDRC, p. 85-87, 1977.

[10] GARRUTI, R. dos S. Metodologia estatístico-sensorial para avaliação do sabor e textura de cultivares de feijão (Phaseolus vulgaris L.) armazenados. Campinas, 1981. 259 p. Tese de Livre - Docência, Universidade Estadual de Campinas (UNICAMP).

[11] GOMES, F. P. Curso de Estatística Experimental. São Paulo: Nobel, Experimentos Fatoriais, p. 96-125, 1990.

[12] GUEVARA, L. L. V. Avaliação sensorial e inativação de lipoxigenase em feijão (Phaseolus vulgaris L.) armazenados em condições ambientais. Lavras, 1990. 132 p. Dissertação (Mestre em Ciência dos Alimentos) - Universidade Federal de Lavras (UFLA).

[13] IADEROZA, M.; SALES, A. M.; BALDINI, V. L. S.; SARTORI, M. R. e FERREIRA, V. L. P. Polyphenol oxidase activity and alterations in colour and levels of condensend tannins during storage of new bean (Phaseolus) cultivars. Coletânea do Instituto de Tecnologia de Alimentos, Campinas, v.19, n.2, p. 154-164, 1989.
[14] JUNEK, J. J.; SISTRUNK, W. A.; NEELY, M. B. Influence of processing methodology in quality attributes of canned dry beans. Journal of Food Science, Chicago, v.45, n.4, p. $821,1980$.

[15] LAJolo, F. M.; Genovese, M. I.; MeneZES, E. W. Qualidade Nutricional. In.: ARAUJO, R. S.; AGUSTÍN RAVA, C.; STONE, L. F.; ZIMMERMANN, M. J. de O. (coords.). Cultura do feijoeiro comum no Brasil. Piracicaba: Potafos, Sç.2, p. 71-99, 1996.

[16] MARTIN-CABREJAS, M. A.; ESTEBAN, R. M.; PEREZ, P.; MAINA, G.; WALDRON, K. W. Changes in physicochemical properties of dry beans (Phaseolus vulgaris L.) during long-term storage. Journal of Agricultural and Food Chemistry, Washington, v. 45, n.8, p. 3223-3227, 1997.

[17] MOURA, A. C. de C. Análises físico-químicas e enzimáticas antes e após armazenamento em grãos de feijão (Phaseolus vulgaris, L.) submetidos a diferentes tempos e tipos de secagem. Lavras, 1998. 70p. Dissertação (Mestre em Ciência dos Alimentos) - Universidade Federal de Lavras (UFLA).

[18] SARTORI, M. R. Armazenamento. In.: ARAUJO, R. S.; Agustín RAVA, C.; STONE, L. F.; ZIMMERMANN, M. J. de O. (coords.). Cultura do feijoeiro comum no Brasil. Piracicaba: Potafos, Sç.3, p. 543-562, 1996.

[19] SGARBIERI, V. C. 1987. Alimentação e Nutrição fator de saúde e desenvolvimento. Campinas, Universidade Estadual de Campinas (UNICAMP).

[20] STANLEY, D. W. A possible role for condensed tannins in bean hardening. Food Research International, New York, v.25, n.3, p. 187-192, 1992.

[21] SWAIN, T.; HILlis, W. E. The phenolic constituents of Prumus domestica I. The quantitative analysis of phenolic constituents. Journal of the Science of Food and Agriculture, London, v.10, n.1, p. 63-68, 1959.

[22] TIBURCiO, G. T. Alteração na Composição Centesimal nos Polifenólicos e na Digestibilidade in vitro da Proteína em Seis Variedades de Feijão Alado (Psophocarpus tetragonolobus) após Armazenamento. Belo Horizonte, 1992. 54 p. Dissertação (Mestre em Ciência dos Alimentos - Faculdade de Farmácia, Universidade Federal de Minas Gerais (UFMG). 